\title{
EFEKTIVITAS PENGGUNAAN MODEL THINK TALK WRITE BERBANTUAN MEDIA KOMIK STRIP DALAM PENINGKATAN KETERAMPILAN MENULIS DIALOG SEDERHANA SISWA KELAS V SD 1 TRITIS
}

\author{
Sony Ari Wibowo ${ }^{1}$, Mila Roysa ${ }^{2}$ \\ 201433135@std.umk.ac.id ${ }^{1}$, mila.roysa@umk.ac.id ${ }^{2}$
}
Program Studi Pendidikan Guru Sekolah Dasar, Fakultas Keguruan dan Ilmu Pendidikan, Universitas Muria Kudus, Indonesia ${ }^{1}$

Program Studi Pendidikan Bahasa dan Sastra Indonesia, Fakultas Keguruan dan Ilmu Pendidikan, Universitas Muria Kudus, Indonesia ${ }^{2}$

\begin{abstract}
This study aims to describe the increase in student activity and the skills of writing a simple dialogue of the students of grade V SD 1 Tritis using a talk-assisted think-write model of comic strip media. The method used in this research is Classroom Action Research(CAR) which is implemented in two cycles, each cycle consists of planning, implementation, observation, and reflection. Classroom action research was conducted in class V SD 1 Tritis Nalumsari Jepara with research subject 28 students. The results showed that the use of comic strip media can improve student activity and writing skills of simple dialogue of students. This can be seen from the achievement of the indicators of success are: (1) student learning activities in learning Indonesian writing materials simple dialogue on the first cycle total score 17 with a percentage of 69\% (good criteria) while in second cycle the total score of 20 with the percentage of $81 \%$ (very good criteria). (2) the percentage of students' learning mastery in Indonesian language lesson writing simple dialogue in first cycle obtained by classical average completeness 67 with percentage of $71 \%$ and increased in second cycle obtained by classical average completeness 84 with $89 \%$ percentage. Thus, the application of think-write write-assisted model of comic strip media can improve student activity and writing skills of simple dialogue of grade V SD 1 Tritis Nalumsari Jepara 2017/2018.
\end{abstract}

keywords: writing skills, simple dialogue, think talk write model, comic strip media.

\section{Abstrak}

Penelitian ini bertujuan untuk mendeskripsikan peningkatan aktivitas siswa dan keterampilan menulis dialog sederhana siswa kelas V SD 1 Tritis menggunakan model think talk write berbantuan media komik strip. Metode yang digunakan dalam penelitian ini adalah Penelitian Tindakan Kelas (PTK) yang dilaksanakan dalam dua siklus, setiap siklus terdiri dari perencanaan, pelaksanaan, pengamatan, dan refleksi. Penelitian tindakan kelas dilaksanakan di kelas V SD 1 Tritis Nalumsari Jepara dengan subjek penelitian 28 siswa. Hasil penelitian menunjukkan bahwa penggunaan media komik strip dapat meningkatkan aktivitas siswa dan keterampilan menulis dialog sederhana siswa. Hal ini terlihat dari tercapainya indikator keberhasilan yakni: (1) aktivitas belajar siswa dalam pembelajaran bahasa Indonesia materi menulis dialog sederhana pada siklus I total skor rata-rata 17 dengan persentase $69 \%$ kriteria "baik" sedangkan pada siklus II total skor rata-rata 20 dengan persentase $81 \%$ kriteria "sangat baik". (2) persentase ketuntasan belajar siswa pada pelajaran bahasa Indonesia materi menulis dialog sederhana pada siklus I diperoleh rata-rata ketuntasan klasikal 67 dengan persentase $71 \%$ dan meningkat pada siklus II diperoleh rata-rata ketuntasan klasikal 84 dengan persentase 89\%”. Dengan demikian, penerapan model think talk write berbantuan media komik strip dapat meningkatkan aktivitas siswa dan keterampilan menulis dialog sederhana siswa kelas V SD 1 Tritis Nalumsari Jepara 2017/2018.

kata kunci: keterampilan menulis, dialog sederhana, model think talk write, media komik strip.

\section{PENDAHULUAN}

Pendidikan memegang peranan penting dalam mempersiapkan sumber daya manusia yang berkualitas dan mampu berkompetisi dalam perkembangan ilmu pengetahuan dan teknologi di era globalisasi saat ini. Pendidikan di Indonesia tidak terlepas dari pembelajaran di sekolah baik sekolah dasar, menengah, dan atas. Sekolah dasar merupakan salah satu lembaga pendidikan formal yang bertugas membentuk karakter pengetahuan, sikap, dan keterampilan dasar siswa guna menyiapkan untuk melanjutkan kejenjang yang lebih tinggi. Sebagai tempat awal 
peningkatan kualitas sumber daya manusia, maka diperlukan upaya-upaya untuk meningkatkan kualitas pembelajaran di sekolah dasar agar pembelajaran dapat berjalan dengan efektif dan efisien. Endarmoko (2009: 166), menyatakan efektif merupakan tepat guna atau membawa hasil, sehingga efektivitas pembelajaran dapat diartikan sebagai pencapaian tujuan pembelajaran yang telah ditentukan guru melalui model dan media yang ditentukan pada setiap proses pembelaran. Siswa akan terdorong untuk belajar manakala mereka memiliki minat untuk belajar. Oleh sebab itu perlu sebuah upaya untuk menumbuhkan minat siswa untuk belajar dalam suatu proses pembelajaran yang sedang berlangsung. Salah satunya dengan mengembangkan motivasi belajar siswa dengan mengembangkan sebuah model disertai dengan penggunaan media dalam proses pembelajaran.

Bahasa Indonesia merupakan bahasa pemersatu bagi bangsa Indonesia. Setiap warga negara Indonesia diharuskan mampu menguasai bahasa Indonesia dengan baik dan benar agar mampu berinteraksi dengan baik dan benar, baik dengan keluarga maupun masyarakat luas baik dari suku bangsa yang sama maupun suku bangsa yang berbeda. Bahasa Indonesia memiliki empat ketempilan berbahasa Murtono (2010: 3), menguraikan ada empat keterampilan berbahasa (language skills) yang menjadi muara akhir penggunaan bahasa Indonesia. Keempat keterampilan yang dimaksud adalah keterampilan menyimak (listening skill), keterampilan membaca (reading skill), keterampilan berbicara (speaking skill), dan keterampilan menulis (writing skill).
Keterampilan menulis merupakan suatu keterampilan berbahasa yang dipergunakan untuk berkomunikasi secara tidak langsung, tidak secara tatap muka dengan orang lain. Kegiatan menulis dapat dikatakan sebagai proses ataupun suatu hasil yang dilakukan seseorang untuk menghasilkan karya tulisan. Tarigan (2008: 3), menjelaskan keterampilan menulis ini tidak akan datang secara otomatis, tetapi harus melalui latihan dan praktik yang banyak dan teratur. Menyampaikan ide, gagasan, maupun pikiran melalui bahasa tulis bukanlah pekerjaan yang mudah, terutama bagi para pemula khususnya siswa sekolah dasar.

Salah satu materi dalam mata pelajaran bahasa Indonesia khususnya dalam aspek keterampilan menulis di kelas V adalah menulis dialog sederhana. Waluyo (2007: 20), menjelaskan dialog adalah ciri khas suatu drama, dalam penyusunan dialog pengarang harus memperhatikan pembicaraan tokoh-tokoh dalam kehidupan sehari-hari dan ragam bahasa yang digunakan adalah ragam bahasa lisan yang komunikatif dan bukan ragam bahasa tulis. Dengan bahasa manusia dapat berkomunikasi dan berinteraksi dengan sesama, saling menukarkan pengalaman, saling mengemukakan dan menerima pikiran, serta saling mengekspresikan ide gagasan. Dialog sederhana dalam penelitian ini adalah karya tulis yang disajikan dalam sebuah bentuk percakapan dua orang atau lebih yang dibatasi oleh tema dengan tujuan menyampaikan suatu informasi kepada pembaca.

Kemampuan menulis membutuhkan sebuah daya khayal dan imajinasi yang tinggi untuk menghasilkan sebuah hasil tulisan. Namun kenyataannya, daya khayal dan imajinasi pada siswa sekolah dasar 
masih tergolong rendah dan perlu sebuah motivasi dari guru untuk menumbuhkannya. Berdasarkan observasi prasiklus yang telah dilaksanakan di SD 1 Tritis Kecamatan Nalumsari Kabupaten Jepara diperoleh data rendahnya kemampuan menulis dialog sederhana disebabkan oleh beberapa faktor, antara lain siswa yang pasif dalam kegiatan pembelajaran, siswa tidak dilibatkan dalam kerja kelompok selama proses pembelajaran, siswa tidak berani bertanya kepada guru, siswa kesulitan memunculkan sebuah ide gagasan dalam bentuk tulisan, guru sudah berinovasi dalam mengembangkan

kegiatan pembelajaran dengan menggunakan beberapa model pembelajaran tetapi belum maksimal, dan guru belum menggunakan media pembelajaran secara optimal.

Sebagai salah satu alternatif untuk mengatasi permasalahan tersebut berkaitan dengan proses pembelajaran diperlukan sebuah model pembelajaran yang bersifat PAKEM (Pembelajaran Aktif, Kreatif, Efektif, dan Menyenangkan), pelaksaanaan pembelajaran pada saat ini perlu diarahkan pada pembelajaran yang lebih mementingkan pada keaktifan siswa. Isjoni (2012: 23), menyatakan pembelajaran kooperatif adalah suatu model pembelajaran yang saat ini banyak digunakan untuk mewujudkan kegiatan belajar mengajar yang berpusat pada siswa (studend oriented). Salah satu model pembelajaran kooperatif yang dapat digunakan oleh guru dalam pembelajaran adalah model pembelajaran think talk write, melalui model pembelajaran think talk write diharapkan dapat mengoptimalkan proses pembelajaran guna meningkatkan keterampilan menulis dialog sederhana pada mata pelajaran bahasa Indonesia. Shoimin (2014: 212), menjelaskan model pembelajaran think talk write merupakan suatu model pembelajaran untuk melatih keterampilan peserta didik dalam menulis. Siswa akan memahami secara bermakna dan mendalam dalam proses pembelajaran bahasa Indonesia pada aspek keterampilan menulis.

Kegiatan menulis dialog sederhana dengan model think talk write akan lebih optimal apabila ditunjang dengan penggunaan media pembelajaran. Pemanfaatan media pembelajaran memberikan pengetahuan kepada siswa melalui pengalaman langsung sehingga pembelajaran lebih bermakna, dalam keadaan ini media dapat digunakan agar lebih memberikan pengetahuan yang konkret dan tepat serta mudah dipahami oleh siswa. Media yang dikembangkan dalam penelitian ini adalah media komik, hal ini dipilih dengan mempertimbangkan pada kondisi siswa yaitu, komik mampu menyajikan gambaran cerita secara konkret dengan ilustrasi gambar dan dialog kepada siswa, penggunaan media komik mudah baik bagi guru dan siswa karena komik bisa dibaca kapan saja dan dimana saja. Nurgiyantoro (2010: 408), menyatakan komik sebagai sesuatu yang berkaitan dengan hal-hal yang tidak serius, santai, hiburan ringan, lucu, dan lain-lain yang tidak terlalu memberatkan. Komik yang digunakan dalam penelitian ini merupakan komik berjenis strip yang hanya terdiri dari beberapa panel gambar saja, namun dilihat dari segi isi komik strip ini telah mengungkapkan sebuah gagasan yang utuh yang umumnya hanya melibatkan satu fokus pembicaraan atau satu tema. Dengan menggunakan model dan media ini keterampilan menulis dialog sederhana siswa kelas V SD 1 Tritis dapat meningkat. 
Berdasarkan uraian permasalahan mengenai menulis dialog sederhana pada siswa kelas V SD 1 Tritis, peneliti mengkaji dan melakukan perbaikan pembelajaran melalui penelitian tindakan kelas dengan judul penelitian "peningkatan keterampilan menulis dialog sederhana menggunakan model think talk write berbantuan media komik strip pada siswa kelas V SD 1 Tritis". Penelitian ini bertujuan untuk (1) Mendeskripsikan peningkatan aktivitas siswa kelas V SD 1 Tritis dalam pembelajaran menulis dialog sederhana menggunakan model pembelajaran think talk write berbantuan media komik strip. (2) mendeskripsikan peningkatan keterampilan menulis dialog sederhana siswa kelas V SD 1 Tritis menggunakan model think talk write berbantuan media komik strip.

\section{KAJIAN PUSTAKA}

\section{Efektivitas pembelajaran}

Endarmoko (2009:

166), menyatakan efektif merupakan tepat guna atau membawa hasil, sehingga efektivitas pembelajaran dapat diartikan sebagai pencapaian tujuan pembelajaran yang telah ditentukan guru melalui model dan media yang ditentukan pada setiap proses pembelajaran. Kegiatan pembelajaran yang efektif sangat dibutuhkan oleh anak untuk menumbuhkan daya pikir dengan tanpa mengesampingkan tingkat pemahaman anak sesuai dengan usia perkembangannya. Kurniawan (2012: 370), menjelaskan efektivitas pembelajaran adalah proses pembelajaran yang mencapai hasil belajar sesuai dengan tujuan pembelajaran yang telah ditetapakan.

Kegiatan dapat dikatakan efektif bila kegiatan tersebut dapat diselesaikan tepat pada waktunya dan mencapai tujuan yang telah ditentukan. Rohmawati (2015: 17), menjelaskan efektivitas pembelajaran adalah ukuran keberhasilan dari suatu proses interaksi antar siswa maupun anatara siswa dengan guru dalam situasi edukatif untuk mencapai tujuan pembelajaran. Efektivitas pembelajaran disini tidak semata-mata berorientasi kepada hasil saja, namun juga berorientasi kepada proses dengan harapan semakin tinggi proses yang dilakukan maka semakin tinggi pula hasil yang akan dicapai. Dengan demikian, melalui pengalaman belajarnya (proses) diharapkan siswa mampu menerapkan metode/cara dalam menyelesaikan sebuah masalah yang sedang dihadapi ataupun mampu menghasilkan sebuah karya (hasil).

\section{Keterampilan menulis}

Tarigan (2008: 3), menyatakan kegiatan menulis merupakan suatu keterampilan berbahasa yang dipergunakan untuk berkomunikasi secara tidak langsung atau tidak secara tatap muka dengan orang lain. Menulis merupakan suatu kegiatan yang produktif, artinya dengan menulis kita akan menghasilkan sebuah karya tulisan yang dapat dinikmati atau dibaca oleh pembaca dan menulis merupakan suatu kegiatan yang ekspresif, artinya dengan menulis penulis berupaya mengekspresikan dirinya tentang apa yang sedang dialaminya maupun sebuah kritik sosial terhadap suatu masalah yang sedang terjadi. Nurjamal (2010:68) menyatakan, menulis merupakan sebuah proses kreatif menuangkan gagasan dalam bentuk bahasa tulis untuk tujuan, misalnya memberi tahu, menyakinkan, dan menghibur. Sehingga dapat disimpulkan keterampilan menulis merupakan sebuah keterampilan berbahasa yang digunakan untuk berkomunikasi 
dengan pembaca secara tidak langsung yang dikhususkan untuk penyampaian ide dan gagasan yang kemudian akan dipahami pembaca apa maksud penulis menulis tulisan tersebut.

Dalman (2015: 13), menyatakan menulis memiliki beberapa tujuan, yaitu Tujuan penugasan, Tujuan estetis, Tujuan penerangan, Tujuan pernyataan diri, Tujuan kreatif, dan Tujuan konsumtif. sebuah tulisan juga mempunyai sebuah manfaat dapat mendidik seseorang untuk menambah pengetahuan yang dimilikinya. (Dalman 2015: 6; Saddhono 2014: 161), Menyatakan menulis memiliki banyak manfaat yang dapat dipetik dalam kehidupan diantaranya (1) Peningkatan kecerdasan, Pengembangan daya inisiatif dan kreativitas, (3) Penumbuhan keberanian, (4) Pendorong kemauan dan kemampuan mengumpulkan informasi. Menulis mempunyai berbagai macam tujuan yang disesuaikan dengan apa yang ingin dituliskan oleh seorang penulis dan manfaat yang dapat diambil diantaranya dengan menulis dapat menambah pengetahuan seseorang. Melalui menulis, seorang penulis dapat menyampaikan informasi, ide, dan gagasan yang sedang dipikirkan dan dialaminya melalui sebuah tulisan yang disusun dengan teliti dan cermat. Bila dibandingkan dengan ketiga keterampilan kebahasaan lain, yaitu menyimak, membaca, dan berbicara, keterampilan menulis dapat dikatakan keterampilan berbahasa yang paling kompleks. Susanto (2016: 256), menyatakan langkah-langkah proses menulis sebagai berikut Pramenulis (prewriting), Penyusunan draf tulisan (drafting), Tahap perbaikan (revisi), Tahap penyuntingan (editing), Tahap pemublikasian (publishing). Setiap langkah-langkah menulis saling terikat dan tidak bisa terpisah antara satu langkah dengan yang lainnya. Oleh karena itu seorang penulis harus melewati setiap langkah-langkah tersebut.

\section{Hakikat dialog}

Endarmoko (2009: 156), menjelaskan dialog adalah percakapan atau tanya jawab antara dua orang atau lebih yang bertujuan mendiskusikan dan bertukar pikiran mengenai informasi. Dalam kegiatan percakapan atau dialog tidak hanya dilakukan oleh dua orang, tetapi dialog juga dapat dilakukan oleh lebih dari dua orang. Waluyo (2007: 20), menjelaskan dialog adalah ciri khas suatu drama, dalam penyusunan dialog pengarang harus memperhatikan pembicaraan tokohtokoh dalam kehidupan sehari-hari dan ragam bahasa yang digunakan adalah ragam bahasa lisan yang komunikatif dan bukan ragam bahasa tulis. Dialog dalam kehidupan sehari-hari berfungsi sebagai sarana penyampaian pesan kepada orang lain. Selanjutnya Suyatno (2008: 52), Menyatakan langkahlangkah dalam menulis dialog sebagai berikut.

a. Menentukan topik

b. Menentukan tokoh dan karakter

c. Menyusun butir-butir dialog yang akan dibicarakan dalam dialog

d. Mengembangkan butir-butir dialog.

Dialog sederhana dalam penelitian ini adalah karya tulis yang disajikan dalam sebuah bentuk percakapan dua orang atau lebih yang dibatasi oleh tema dengan tujuan menyampaikan suatu informasi kepada pembaca.

\section{Model think talk write}

Suasana belajar yang nyaman dan kondusif perlu diciptakan oleh guru dalam sebuah proses pembelajaran agar siswa tidak merasa tertekan dan merasa 
bosan dengan kegiatan pembelajaran yang sedang meraka lakukan. Sebuah suasana belajar dan rasa kebersamaan yang tumbuh dan berkembang di antara sesama anggota kelompok memungkinkan siswa untuk mengerti dan memahami materi pelajaran dengan baik, dengan sebuah model pembelajaran kooperatif dapat menumbuhkan suasana belajar dan rasa kebersamaan antar anggota kelompok sehingga akan memudahkan guru untuk mencapai tujuan pembelajaran yang diinginkan. Dalam penelitian ini, peneliti menggunakan salah satu model kooperatif tipe think talk write. Shoimin (2014: 212), menjelaskan model think talk write merupakan suatu model pembelajaran untuk melatih keterampilan peserta didik dalam menulis. Model think talk write akan mengembangkan keterampilan menulis siswa dalam belajar membuat maupun mengekspresikan ide dan gagasan yang mereka pikirkan dalam bentuk tulisan. Huda (2014: 218) menyatakan langkahlangkah model think talk write sebagai berikut Siswa membaca teks dan membuat catatan dari hasil bacaan secara individual, untuk dibawa keforum diskusi. (think), Siswa berinteraksi dan berkolaborasi dengan teman satu grup untuk membahas isi catatan. (talk), Siswa mengkontruksikan sendiri pengetahuan dalam bentuk tulisan. (write), Kegiatan akhir pembelajaran adalah membuat refleksi dan kesimpulan atas materi yang dipelajari.

Shoimin (2014: 215), menyatakan keunggulan model think talk write sebagai berikut Mengembangkan pemecahan yang bermakna dalam memahami materi ajar, Dengan memberikan soal open ended dapat mengembangkan keterampilan berpikir kritis dan kreatif siswa, Dengan berinteraksi dan berdiskusi dengan kelompok akan melibatkan siswa secara aktif dalam belajar, Membiasakan siswa berpikir dan berkomunikasi dengan teman, guru, bahkan dengan diri mereka sendiri. Selanjutnya Hamdayama (2014: 222), menyatakan kelemahan model think talk write sebagai berikut Ketika siswa bekerja dalam kelompok itu mudah kehilangan kemampuan dan kepercayaan, karena didominasi oleh siswa yang mampu, Guru harus benarbenar menyiapkan semua media dengan matang agar dalam menerapkan strategi think talk write tidak mengalami kesulitan. Keunggulan model think talk write diharapkan mampu meningkatkan keterampilan menulis dialog sederhana pada siswa, sedangkan kekurangan model ini akan diminimalisir dengan penggunaan media komik strip.

\section{Media komik}

Penggunaan sebuah media pembelajaran siswa akan memperoleh pengetahuan melalui pengalaman langsung sehingga pembelajaran lebih bermakna, dalam keadaan ini media dapat digunakan agar lebih memberikan pengetahuan yang konkret dan tepat serta mudah dipahami oleh siswa. Dalam penelitian ini, peneliti menggunakan media pembelajaran komik strip. Sudjana (2015: 64), menyatakan komik merupakan suatu bentuk kartun yang mengungkapkan karakter dan memerankan suatu cerita dalam urutan yang erat dihubungkan dengan gambar dan dirancang untuk memberikan hiburan kepada para pembaca. media komik dapat digunakan sebagai media pembelajaran dalam dunia pendidikan jika dirancang sesuai dengan kebutuhan dan materi yang ingin disampaikan. Nurgiyantoro (2010: 434), menyatakan Komik strip adalah komik yang hanya terdiri dari 
beberapa panel gambar saja, namun dilihat dari segi isi ia telah mengungkapkan sebuah gagasan yang utuh.

\section{Aktivitas siswa}

Perilaku siswa dalam sebuah proses pembelajaran yang terjadi di dalam kelas maupun diluar kelas dapat dikatakan sebagai sebuah aktivitas siswa. Oleh karenanya aktivitas siswa tidak hanya sebatas mendengarkan dan mencatat materi yang disampaikan oleh guru saja. Selain peran guru dan media pembelajaran, aktivitas siswa juga akan berpengaruh terhadap hasil belajar siswa. Paul D. Dierich (dalam Hamalik 2015: 172), membagi kegiatan belajar dalam 8 kelompok, diantaranya.

a. Kegiatan-kegiatan visual

Membaca, melihat gambar-gambar, mengamati eksperimen, demonstrasi, pameran, dam mengamati orang lain bekerja atau bermain.

b. Kegiatan-kegiatan lisan (oral)

Mengemukakan suatu fakta atau prinsip, menghubungkan suatu kejadian, mengajukan pertanyaan, memberi saran, mengemukakan pendapat, wawancara, diskusi, dan interupsi.

c. Kegiatan-kegiatan mendengarkan

Mendengarkan penyajian bahan, mendengarkan percakapan atau diskusi kelompok, mendengarkan suatu permainan, mendengarkan radio.

d. Kegiatan-kegiatan menulis

Menulis cerita, menulis laporan, memeriksa karangan, bahan-bahan kopi, membuat rangkuman, mengerjakan tes, dan mengisi angket.

e. Kegiatan-kegiatan menggambar

Menggambar, membuat grafik, chart, diagram peta, dan pola.

f. Kegiatan-kegiatan metrik

Melakukan percobaan, memilih alatalat, melaksanakan pameran, membuat

154 | Jurnal Kredo

Vol. 1 No. 2 April 2018 model, menyelenggarakan permainan, menari, dan berkebun.

g. Kegiatan-kegiatan mental

Merenungkan, mengingat, memecahkan masalah, menganalisis, faktor-faktor, melihat, hubunganhubungan, dan membuat keputusan.

h. Kegiatan-kegaiatan emosional

Minat, membedakan, berani, tenang, dan lain-lain. Kegiatan-kegiatan dalam kelompok ini terdapat dalam semua jenis kegiatan dan overlap satu sama lain.

Proses pembelajaran yang berorientasi pada aktivitas siswa artinya, siswa menjadi subjek dalam proses pembelajaran hal ini dikarenakan yang menjadi sasaran dalam dalam pembelajaran adalah aktivitas siswa karena aktivitas siswa akan menjadi sebuah tolak ukur berhasil atau tidaknya suatu pembelajaran.

Berdasarkan kajian teori yang telah dikemukan pada penelitian ini, maka hipotesis tindakan pada penelitian ini dapat dirumuskan sebagai berikut. (1) Penerapan model pembelajaran think talk write berbantuan media komik strip dapat meningkatkan aktivitas siswa dalam pembelajaran menulis dialog sederhana siswa kelas V SD 1 Tritis. (2) Penerapan model pembelajaran think talk write berbantuan media komik strip dapat meningkatkan keterampilan menulis dialog sederhana siswa kelas V SD 1 Tritis.

\section{METODE PENELITIAN}

Jenis Penelitian

Jenis penelitian ini adalah Penelitian Tindakan Kelas (PTK).

Tempat dan Waktu Penelitian

Penelitian ini telah dilaksanakan di SD 1 Tritis Nalumsari Jepara yang 
terletak di Jalan Desa Tritis Kecamatan Nalumsari Kabupaten Jepara. Penelitian ini dilaksanakan pada jadwal kegiatan kelas $\mathrm{V}$ semester 1 mata pelajaran bahasa Indonesia, mulai bulan Juli sampai dengan Desember tahun pelajaran 2017/2018.

\section{Subjek Penelitian}

Subjek dalam penelitian ini adalah guru dan siswa kelas V SD 1 Tritis Tahun Pelajaran 2017/2018 dengan jumlah keseluruhan 28 siswa. Pemilihan subjek penelitian ini didasarkan atas pertimbangan bahwa rendahnya keterampilan menulis pada mata pelajaran bahasa Indonesia Siswa Kelas V SD 1 Tritis Kecamatan Nalumsari Kabupaten Jepara, terutama dalam materi menulis dialog sederhana.

Model siklus yang dijalankan oleh peneliti mengacu pada alur model yang dikembangkan oleh Kemmis dan Mc Taggart yaitu model yang terdiri dari empat komponen: (1) Perencanaan, (2) Pelaksanaan, (3) Pengamatan, (4) Refleksi. Seperti terlihat pada gambar 1 berikut.

Gambar 1. Siklus Penelitian Tindakan Kelas Adaptasi dari Model Kemmis dan Mc. Taggart

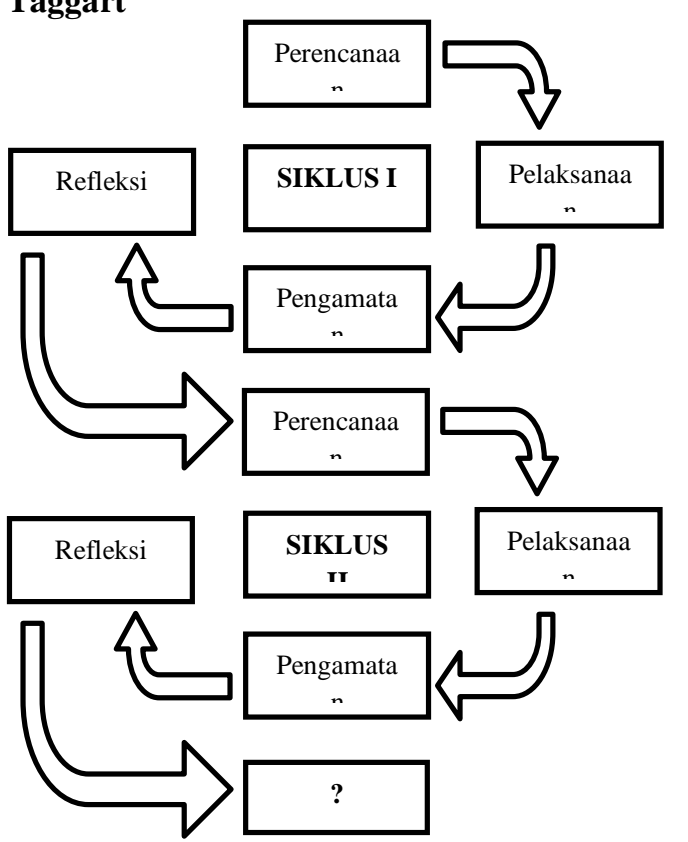

\section{Teknik Pengumpulan Data}

Teknik pengumpulan data dalam penelitian tindakan kelas ini dilakukan melalui Observasi, Wawancara, Tes, dan Dokumentasi. Teknik pengumpulan data dapat dijabarkan sebagai berikut.

\section{Observasi}

Observasi dalam penelitian ini digunakan untuk menggambarkan aktivitas siswa dan keterampilan guru dalam pembelajaran peningkatan keterampilan menulis dialog sederhana menggunakan model think talk write berbantuan media komik strip.

\section{Wawancara}

Wawancara dalam penelitian ini digunakan untuk mengetahui faktorfaktor apa saja yang menjadi penghambat dalam pelaksanaan pembelajaran khususnya pada mata pelajaran bahasa Indonesia keterampilan menulis dialog sederhana. 3. Tes

Tes dalam penelitian ini menggunakan tes tertulis dalam lembar kerja siswa yang digunakan untuk mengukur sejauh mana keterampilan siswa dalam menulis dialog sederhana melalui model think talk write berbantuan media komik strip dan digunakan untuk mengetahui hasil belajar bahasa Indonesia siswa di kelas V SD 1 Tritis dengan materi menulis dialog sederhana melalui model think talk write berbantuan media komik strip.

4. Dokumentasi

Metode dokumentasi dilakukan untuk memperkuat data yang diperoleh dalam observasi. Dokumen yang digunakan dalam penelitian ini berupa daftar nilai siswa. Untuk memberikan gambaran secara konkret mengenai kegiatan kelompok siswa dan menggambarkan suasana kelas ketika aktivitas belajar berlangsung digunakan dokumen foto.

(Sumber: Arikunto, 2012: 16) 


\section{Teknik Analisis Data}

Teknik analisis data yang diperoleh dari penelitian ini berupa data observasi pada saat proses pembelajaran dan soal tes keterampilan menulis dialog sederhana setiap siklus. Adapun teknik analisis data sebagi berikut.

1. Data Kuantitatif

Data kuantitatif dalam penelitian ini berupa hasil belajar yang dianalisis menggunakan teknik analisis deskriptif. Nilai yang diperoleh siswa pada tes digunakan sebagai acuan peningkatan keterampilan menulis dialog sederhana siswa.

2. Data Kualitatif

Data kualitatif pada penelitian ini berupa data pengamatan terhadap pelaksanaan pembelajaran, keterampilan guru dan aktivitas siswa pada pembelajaran materi menulis dialog sederhana melalui model think talk write.

\section{HASIL DAN PEMBAHASAN}

Penelitian ini dilaksanakan pada siswa kelas V SD 1 Tritis Siklus I pada hari Selasa tanggal 21 November 2017 dan Kamis tanggal 23 November 2017. Kemudian dilanjutkan penelitian tindakan kelas siklus II pada hari kamis tanggal 30 November 2017 dan sabtu tanggal 2 Desember 2017. Yang pada setiap pertemuaanya dibedakan oleh materi yang diajarkan.

Hasil analisis pada tahap prasiklus nilai hasil belajar siswa kelas V SD 1 Tritis tahun pelajaran 2016/2017 menunjukkan ketuntasan belajar klasikal hanya mencapai 53\% sedangkan, siswa yang tidak tuntas sebesar $47 \%$, berdasarkan hal tersebut rata-rata hasil belajar bahasa Indonesia siswa kelas V SD 1 Tritis tahun pelajaran 2016/2017 jika dihitung secara klasikal diperoleh nilai 66 sedangkan Kriteria Ketuntasan Minimal (KKM) yang menjadi acuan adalah 75. Hasil analisis prasiklus dapat memberikan gambaran bahwa sebagian besar siswa perlu mendapatkan perhatian dalam peningkatan belajar terutama siswa yang mendapat nilai dibawah KKM.

Tabel 1. Peningkatan nilai keterampilan menulis dialog siswa siklus I dan siklus II

\begin{tabular}{|l|l|l|l|l|l|}
\hline Nila & \multirow{2}{*}{$\begin{array}{c}\text { Ketunta } \\
\text { san } \\
\text { Belajar }\end{array}$} & \multicolumn{2}{|c|}{$\begin{array}{c}\text { Jumlah } \\
\text { Siswa }\end{array}$} & \multicolumn{2}{c|}{ Persentase } \\
\cline { 3 - 6 } & & S I & S II & S I & S II \\
\hline$\geq 75$ & Tuntas & 20 & 25 & $71 \%$ & $89 \%$ \\
\hline$<75$ & $\begin{array}{l}\text { Tidak } \\
\text { Tuntas }\end{array}$ & 8 & 3 & $29 \%$ & $11 \%$ \\
\hline \multicolumn{2}{|l|}{ Jumlah } & 28 & 28 & $100 \%$ & $100 \%$ \\
\hline
\end{tabular}

(Sumber: Data primer, hasil tes evaluasi menulis dialog sederhana siklus I dan II)

\section{Siklus I}

Penelitian tindakan kelas siklus I dilaksanakan selama 2 kali pertemuan yaitu 4 jam pelajaran $(4 \times 35$ menit $)$ pada tanggal 21 November 2017 dan 23 November 2017 yang diikuti oleh 28 siswa. Pada tindakan siklus I kegiatan pembelajaran menulis dialog sederhana siswa dijelaskan bahwa terdapat 20 siswa yang tuntas atau mendapat nilai diatas KKM yaitu AIB, FSI, KAS, LR, LAT, MRSF, MAR, NPAN, NNA, PA, PA, PA, RS, RK, RPP, SA, SA, SMA, ASA, dan DS. Kemudian terdapat 8 siswa yang belum tuntas atau mendapat nilai dibawah KKM yaitu ARF, AAR, EVP, HAY, JAF, LK, NS, dan ZAF. Berdasarkan paparan hasil tes keterampilan menulis dialog sederhana siswa siklus I memperoleh rata-rata nilai klasikal sebesar 67 dengan persentase $71 \%$ dengan kriteria "baik". Perbandingan persentase ketuntasan klasikal keterampilan menulis dialog sederhana siswa siklus I antara siswa yang nilainya tuntas $(\geq 75)$ sebanyak 20 siswa dengan persentase $71 \%$ 
sedangkan siswa yang nilainya belum tuntas $(<75)$ sebanyak 8 siswa dengan persentase $29 \%$. Dilihat dari ketuntasan klasikal pada siklus I yaitu didapatkan nilai rata-rata klasikal 67 dengan persentase $71 \%$ belum memenuhi indikator keberhasilan ketuntasan klasikal yaitu $75 \%$.

Hasil observasi aktivitas belajar siswa selama proses pembelajaran pada siklus I pertemuan 1 memperoleh ratarata skor 16 yang dihitung secara klasikal mencapai persentase $66 \%$ dengan kriteria "baik". Sedangkan pertemuan 2 memperoleh rata-rata skor 18 yang dihitung secara klasikal mencapai persentase $72 \%$ dengan kriteria "baik". Rata-rata hasil pengamatan aktivitas belajar siswa pada pembelajaran siklus I memperoleh rata-rata skor 17 dengan persentase $69 \%$ kriteria "baik". Berdasarkan data tersebut aktivitas belajar siswa belum mencapi indikator keberhasilan yaitu $\geq 75 \%$. Jika dianalisis dari data tersebut kekurangan yang terjadi pada aktivitas siswa disebabkan oleh adanya kekurangan pada keterampilan guru saat mengajar. Akibat dari kekurangankekurangan keterampilan guru dalam mengajar, siswa kurang berantusias hal tersebut karena kurangnya motivasi guru terhadap siswa, siswa kurang bekerjasama antar anggota kelompoknya, disebabkan karena kurang motivasi dari guru kepada siswa untuk saling bekerjasama dalam kelompok, siswa yang sudah selesai ramai sendiri dan berbicara dengan temannya disebabkan karena guru kurang mampu mengelola kelas dan kurang memperhatikan siswa yang ramai.

\section{Siklus II}

Penelitian tindakan kelas siklus II dilaksanakan selama 2 kali pertemuan yaitu 4 jam pelajaran (4x35 menit) pada hari Kamis tanggal 30 November
2017 dan pada hari Sabtu tanggal 2 Desember 2017 yang diikuti oleh 28 siswa. Pada tindakan siklus II kegiatan pembelajaran menulis dialog sederhana melalui penerapan model think talk write berbantuan media komik strip mengalami peningkatan yang signifikan. Hasil penelitian diketahui bahwa terdapat 25 siswa yang tuntas atau mendapat nilai diatas KKM yaitu AAR, AIB, FSI, HAY, KAS, LR, LAT, LK, MRSF, MAR, NPAN, NNA, NS, PA, PA, PA, RS, RK, RPP, SA, SA, SMA, ZAF, ASA, dan DS. Kemudian terdapat 3 siswa yang belum tuntas atau mendapat nilai dibawah KKM yaitu ARF, EVP, dan JAF. Berdasarkan paparan hasil tes keterampilan menulis dialog sederhana siswa siklus II memperoleh rata-rata nilai klasikal sebesar 84 dengan persentase $89 \%$ dengan kriteria "sangat baik". Perbandingan persentase ketuntasan klasikal keterampilan menulis dialog sederhana siklus II antara siswa yang nilainya tuntas $(\geq 75)$ sebanyak 25 siswa dengan persentase $89 \%$ sedangkan siswa yang nilainya belum tuntas $(<75)$ sebanyak 3 siswa dengan persentase $11 \%$. Dilihat dari ketuntasan klasikal pada siklus II yaitu didapatkan nilai rata-rata klasikal 84 dengan persentase $89 \%$ berada pada kriteria "sangat baik" dan dapat disimpulkan bahwa nilai keterampilan menulis dialog sederhana siswa pada siklus II sudah memenuhi indikator keberhasilan ketuntasan klasikal yang ditetapkan oleh peneliti yaitu $\geq 75$ dengan persentase ketuntasan klasikal minimal $75 \%$ dengan kriteria "sangat baik".

Hasil observasi aktivitas belajar siswa selama proses pembelajaran pada siklus II pertemuan 1 memperoleh ratarata skor 20 yang dihitung secara klasikal mencapai persentase $79 \%$ dengan kriteria "baik". Sedangkan 
pertemuan 2 memperoleh rata-rata skor 21 yang dihitung secara klasikal mencapai persentase $84 \%$ dengan kriteria "sangat baik". Rata-rata hasil pengamatan aktivitas belajar siswa pada pembelajaran siklus II memperoleh rata-rata skor 20 dengan persentase $81 \%$ kriteria "sangat baik".

Gambar 2. Diagram peningkatan aktivitas belajar siswa siklus I dan siklus II

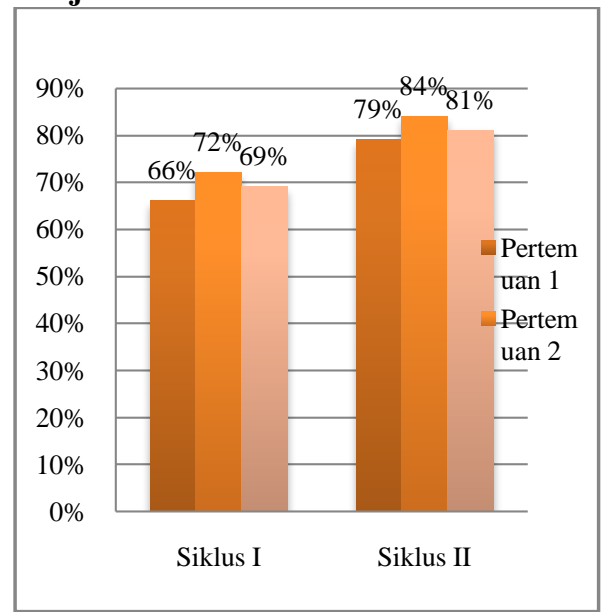

(Sumber: Data primer, hasil observasi aktivitas belajar siswa siklus I dan Siklus II)

Berdasarkan hasil penelitian penerapan model think talk write berbantuan media komik strip yang telah dilaksanakan pada siklus I,walaupun terjadi peningkatan tetapi masih ada beberapa siswa yang belum mampu memenuhi kriteria yang ditargetkan. Bertolak dari kendalakendala yang dihadapi pada siklus I, maka perbaikan tindakan yang dilakukan pada siklus II adalah: guru lebih memotivasi dan menjelaskan tentang arti kerja sama dalam satu kelompok. Masalah-masalah yang yang muncul pada siklus I seperti siswa kurang berantusias, siswa kurang bekerjasama dalam kelompok, dan siswa yang ramai sendiri. Dapat diminimalkan dengan memotivasi dan menjelaskan tentang arti kerja sama, sehingga setiap siswa mampu bekerja dan bertanggung jawab dalam kelompoknya. Berdasarkan hasil observasi aktivitas siswa pada siklus I dan siklus II dapat disimpulkan adanya peningkatan aktivitas belajar siswa selama pembelajaran bahasa Indonesia keterampilan menulis dialog sederhana menggunakan model think talk write berbantuan media komik strip dari hasil rata-rata hasil observasi siklus I ke siklus II yaitu $69 \%$ menjadi $81 \%$.

Gambar 2. Diagram peningkatan persentase ketuntasan belajar siklus I dan siklus II

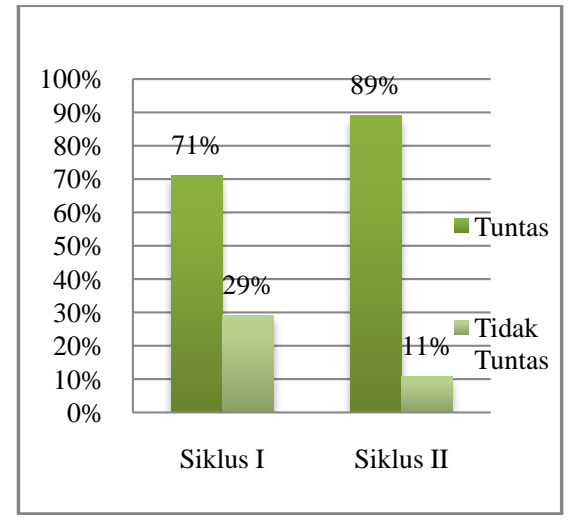

(Sumber: Data primer, hasil tes evaluasi menulis dialog sederhana siklus I dan II)

Hasil penelitian dengan menggunakan model think talk write berbantuan media komik strip mengalami kenaikan yang cukup signifikan. Dilihat dari ketuntasan klasikal pada siklus I yaitu didapatkan nilai rata-rata klasikal 67 dengan persentase $71 \%$ berada pada kriteria "baik" dan pada siklus II didapatkan nilai rata-rata klasikal 84 dengan persentase $89 \%$ berada pada kriteria "sangat baik". Peningkatan tersebut dikarenakan guru menerapkan model pembelajaran think talk write pada saat pembelajaran berlangsung. Model pembejaran tersebut juga dibantu dengan media komik strip. Grafik tersebut menunjukkan peningkatan yang signifikan terjadi pada keterampilan menulis dialog sederhana siswa dari siklus I hingga siklus II. Oleh karena itu, dapat disimpulkan bahwa pembelajaran bahasa Indonesia 
dengan menggunakan model pembelajaran think talk write berbantuan media komik strip dapat meningkatkan keterampilan menulis dialog sederhana siswa pada kelas $\mathrm{V}$ SD 1 Tritis Nalumsari Jepara Tahun Pelajaran 2017/2018.

\section{SIMPULAN DAN SARAN}

\section{Simpulan}

Berdasarkan hasil penelitian dan pembahasan yang telah diuraikan terhadap pembelajaran bahasa Indonesia pada materi keterampilan menulis dialog sederhana menggunakan model think talk write berbantuan media komik strip. Dapat diambil simpulan. (1) Aktivitas belajar siswa kelas V semester 1 SD 1 Tritis Nalumsari Jepara dalam mengikuti pembelajaran bahasa Indonesia materi menulis dialog sederhana Pada siklus I diperoleh total skor rata-rata 17 dengan persentase $69 \%$ kriteria "baik", sedangkan pada siklus II total skor ratarata 20 dengan persentase $81 \%$ kriteria "sangat baik". (2) Keterampilan menulis dialog sederhana siswa kelas $\mathrm{V}$ SD 1 Tritis materi keterampilan menulis dialog sederhana tahun pelajaran 2017/2018 Pada siklus I diperoleh rata-rata ketuntasan klasikal 67 dengan persentase $71 \%$ nilai tertinggi 93 dan nilai terendah 25 dan meningkat pada siklus II diperoleh rata-rata ketuntasan klasikal 84 dengan persentase $89 \%$ nilai tertinggi 100 dan nilai terendah 31. sehingga hasil keterampilan menulis dialog sederhana siswa termasuk dalam kriteria "baik" pada siklus I dan meningkat pada siklus II dengan tingkat keberhasilan "sangat baik".

\section{Saran}

Berdasarkan penelitian dengan menerapkan model think talk write berbantuan media komik strip dalam pembelajaran bahasa Indonesia materi menulis dialog sederhana pada siswa kelas V SD 1 Tritis tahun pelajaran 2017/2018, maka peneliti mengajukan saran sebagai berikut.

1. Bagi Guru

a. Guru hendaknya menerapkan inovasi-inovasi yang sesuai dengan pembelajaran yang dapat diterapkan pada proses pembelajaran sehingga pembelajaran menjadi menyenangkan.

b. Guru hendaknya selalu menciptakan suasana pembelajaran yang bernuansa sosial dan membimbing siswa secara intensif dalam pembelajaran.

c. Guru hendaknya menerapkan pembelajaran dengan menggunakan model pembelajaran yang dapat memberikan pengalaman bermakna bagi siswa untuk perkembangan keterampilan sosial serta partisipasi siswa.

d. Guru hendaknya memberikan kesempatan kepada siswa untuk mengembangkan kreativias dan pengetahuannya sesuai kemampuan masing-masing siswa serta melatih siswa untuk berinteraksi dengan siswa lain, dapat bekerja sama, dan bertanggung jawab dengan cara menerapkan diskusi kelompok pada kegiatan pembelajaran.

e. Guru hendaknya selalu memberikan motivasi agar siswa lebih bersemangat untuk berlatih dalam menulis sehingga dapat menghasilkan tulisan yang semakin baik dan sistematis. 
2. Bagi Siswa

a. Siswa hendaknya pada saat kegiatan pembelajaran memperhatikan penjelasan dari guru dan terlibat aktif untuk mengajukan pertanyaan apabila belum paham dengan materi yang dijelaskan, menjawab pertanyaan dari guru serta memberikan gagasannya tentang materi yang dipelajari.

b. Siswa hendaknya terlibat secara aktif dan bersungguh-sungguh dalam kegiatan pembelajaran maupun pada saat mengerjakan tes sehingga hasil belajar dapat tercapai secara maksimal.

c. Siswa hendaknya berlatih berbicara di depan kelas supaya saat diminta guru untuk berbicara di depan temannya siswa tidak takut.

3. Bagi Sekolah

a. Penelitian tindakan kelas ini hendaknya dijadikan alat evaluasi bagi sekolah untuk berinovasi menciptakan pembelajaran berkualitas.

b. Sekolah hendaknya menyediakan sarana dan prasarana yang diperlukan untuk memperlancar proses pembelajaran, termasuk media-media pembelajaran yang lebih variatif sehingga dapat menumbuhkan semangat siswa dalam mengikuti pembelajaran.

\section{DAFTAR PUSTAKA}

Arikunto, Suharsimi, dkk. 2012. Penelitian Tindakan Kelas. Jakarta: Bumi Aksara.

Dalman. 2015. Keterampilan Menulis. Jakarta: PT Rajagrafindo Persada. Endarmoko, Eko. 2009. Tesaurus Bahasa Indonesia. Jakarta: PT Gramedia.

Hamdayama, Jumanta. 2014. Model dan Metode Pembelajaran Kreatif dan Berkarakter. Bogor: Ghalia Indonesia

Hamalik, Oemar. 2015. Proses Belajar Mengajar. Jakarta: PT Bumi Aksara.

Huda, Miftahul. 2014. Model-model Pengajaran dan Pembelajaran: Isu-isu Metodis dan Paradigmatis. Yogyakarta: Pustaka Pelajar.

Isjoni. 2012. Pembelajaran Kooperatif Meningkatkan Kecerdasan Komunikasi antar Peserta Didik. Yogyakarta: Pustaka Pelajar.

Kurniawan, Heru. 2012. Upaya Peningkatan Efektivitas Pembelajaran Matematika Melalui Model Pembelajaran Kooperatif Tipe Team Assisted Individualization (TAI) pada Siswa Kelas V SD Negeri Sidomulyo Tahun Pelajaran 2011/2012.Prosiding. Yogyakarta: Universitas Negeri Yogyakarta. 
Murtono. 2010. Menuju Kemahiran Berbahasa Indonesia (Langkah Maju Menulis Karya Ilmiah). Surakarta: UNS Pres.

Nurgiyantoro, Burhan. 2010. Sastra Anak Pengantar Pemahaman Dunia Anak. Yogyakarta: BPFE-Yogyakarta.

Nurjamal, Daeng dan Warta Sumirat. 2010. Penuntun Perkuliahan Bahasa Indonesia untuk Memandu Acara: MC-Moderator, Karya Tulis Akademik, dan Surat-Menyurat. Bandung: CV ALFABETA.

Rohmawati, Afifatu. 2015. Efektivitas Pembelajaran. Jurnal Pendidikan Usia Dini. Volume 9. Hal 15-32.

Saddhono, Kundharu dan St. Y. Slamet. 2014. Pembelajaran Keterampilan Berbahasa Indonesia (Teori dan Aplikasi). Yogyakarta: Graha Ilmu.

Shoimin, Aris. 2014. 68 Model Pembelajaran Inovatif dalam Kurikulum 2013. Yogyakarta: Ar-Ruzz Media.

Sudjana, Nana dan Ahmad Rivai. 2015. Media Pengajaran. Bandung: Sinar Baru Algensindo Bandung.

Susanto, Ahmad. 2016. Teori Belajar dan Pembelajaran di Sekolah Dasar. Jakarta: Prenadamedia Group.

Suyatno, dkk. 2008. Indahnya Bahasa dan Sastra Indonesia: untuk SD/MI Kelas $V$. Jakarta: Pusat Perbukuan, Departemen Pendidikan Nasional.

Tarigan, Henry Guntur. 2008. Menulis Sebagai Suatu Keterampilan Berbahasa. Bandung: Angkasa Bandung.

Waluyo, Herman J. 2007. Drama Naskah, Pementasan, dan Pengajarannya. Surakarta: LPP UNS dan UNS Press. 